\title{
Controversies in the Use of Passive Immunotherapy for Bacterial Infections in the Critically Ill Patient
}

\author{
J. D. Baumgartner and M. P. Glauser
}

From the Division of Infectious Diseases, Department of Internal Medicine, University Medical Center,

Lausanne, Switzerland

\begin{abstract}
Several preparations of standard immunoglobulins for intravenous use have been tested as adjunctive therapy for bacterial infections in premature neonates and in critically ill adults after major surgery, trauma, and burn. The use of intravenous immunoglobulins in these settings is controversial because the efficacy and cost-effectiveness of this treatment are still not definitively established. Specific preparations of immunoglobulins against Pseudomonas aeruginosa for intramuscular administration have shown promising efficacy, and preparations for intravenous administration are now under investigation. Cross-protection against a wide range of gram-negative infections has been attempted by the administration of antiserum to the core glycolipid of lipopolysaccharide prepared from volunteers immunized with the J5 mutant of Escherichia coli 0111. Treatment with this preparation improved the survival rate of patients with gram-negative bacteremia and, when administered prophylactically to high-risk surgical patients, prevented shock and death related to gram-negative infections. The mechanism of protection of the $\mathrm{J} 5$ antiserum is not clearly understood because of our inability to measure the actual protective antibody in polyclonal $\mathrm{J} 5$ antiserum. Thus, the preparation of readily available crossprotective hyperimmune immunoglobulins is hampered because there is presently no method of selecting appropriate donors or high-titered plasma pools.
\end{abstract}

Passive immunotherapy has been used since 1893 when Behring et al. described the administration of immune horse serum for the treatment of a patient with diphtheria [1]. Administration of immune horse serum has since been attempted for the treatment of many other infections. Although this therapy was sometimes successful in the treatment of bacterial infections, it has been largely replaced by antibiotic therapy. At present, the only established uses for passive immunotherapy in the field of infectious diseases are as replacement therapy in primary humoral immunodeficiencies and as prophylaxis for some viral infections and diseases caused by bacterial exotoxins (table 1).

This paper was presented at a symposium, "Controversies in the Diagnosis and Management of Infectious Diseases," held in Laguna Niguel, California, November 10-12, 1985, which was sponsored by the Division of Infectious Diseases/Epidemiology of Columbia University and funded by an educational grant from Smith Kline \&French Laboratories and Fujisawa/SmithKline Corporation.

Please address requests for reprints to Dr. Michel-Pierre Glauser, Division of Infectious Diseases, Department of Medicine, Centre Hospitalier Universitaire Vaudois, Lausanne, Switzerland.
We now realize that antibiotics have their limitations, especially in the treatment of infectious diseases in critically ill patients. Despite the availability of increasingly potent antimicrobial drugs, bacterial infections remain a major cause of death in these patients. Adjunctive therapies, such as immunoprophylaxis or immunotherapy, are investigated to improve the outcome of treatment in critically ill patients. Infections occurring in these patients are most often acute and unexpected. Furthermore, the patients' underlying diseases often preclude the production of sufficient quantities of antibody, even after active immunization. Thus immunotherapy consists mainly of the administration of preformed antibodies, either in the form of immune serum or plasma or in the form of standard or hyperimmune purified immunoglobulins.

This review discusses the advantages and disadvantages of administration of these various forms of antibody to critically ill patients. We will focus on some aspects of passive immunotherapy and mainly on the controversial issues of the passive immunologic approach to treatment of bacterial infections in neonates and surgical patients at high risk of infection, patients with severe burns, and patients with established gram-negative bacteremia. 
Table 1. Established indications for the use of immunoglobulins in the prevention or treatment of infectious diseases.

\begin{tabular}{|c|c|}
\hline $\begin{array}{l}\text { Type of } \\
\text { immunoglobulin }\end{array}$ & Indications for use \\
\hline Standard & $\begin{array}{l}\text { Prophylaxis and treatment of infection in } \\
\text { primary humoral immunodeficiencies } \\
\text { Prophylaxis of hepatitis A infection } \\
\text { Prophylaxis of measles }\end{array}$ \\
\hline Hyperimmune & $\begin{array}{l}\text { Prophylaxis of viral infections } \\
\text { Cytomegalovirus } \\
\text { Hepatitis B } \\
\text { Rabies } \\
\text { Vaccinia } \\
\text { Varicella } \\
\text { Prophylaxis of diseases caused by } \\
\text { bacterial exotoxins } \\
\text { Tetanus } \\
\text { Diphtheria } \\
\text { Botulism* }\end{array}$ \\
\hline
\end{tabular}

* Available only as horse serum.

\section{Relation Between Outcome of Infection in the Critically III Patient and Levels of Antibody to Bacteria}

The role of humoral immunity in host defenses against bacterial infections is well known [2]. In critically ill patients admitted to intensive care units, the major causes of infection and death are gram-negative bacteria [3-6]. Many of the toxic manifestations induced by gram-negative bacterial infections are believed to be mediated by the lipopolysaccharide (LPS, endotoxin) component of the outer membrane of these bacteria. Antibiotics are unable to prevent the toxic effects of LPS and may even promote the release of LPS from bacteria [7].

The importance of antibodies to LPS in the defense against gram-negative infections has been established clinically by studies relating the outcome of infections in patients to titers of specific and crossreactive antibodies at the onset of gram-negative bacteremia. Antibodies directed against the $\mathrm{O}$ antigens, the external part of the LPS, are strain specific. In contrast, antibodies directed against the core glycolipid, the central part of the LPS, may be cross-reactive, since many determinants of the core glycolipid are common among gram-negative bacteria.

Antibodies to the core glycolipid may be measured by use of LPS from rough mutants of gram-negative bacteria that are unable to incorporate the strain-
Table 2. Relation of shock and death $(S+D)$ to antibody titers in patients with gram-negative bacteremia.

\begin{tabular}{|c|c|c|c|}
\hline $\begin{array}{l}\text { Antibody measured } \\
\text { (method of detection) }\end{array}$ & $\begin{array}{c}\text { Antibody } \\
\text { titer }\end{array}$ & $\begin{array}{c}\text { No. of } \\
\text { patients with } \\
S+D / \text { total } \\
\text { no. }(\%)\end{array}$ & $\begin{array}{c}P \\
\text { value }\end{array}$ \\
\hline \multicolumn{4}{|l|}{ Type-specific antibodies* } \\
\hline IgG to $O$ antigens (IF) & $\begin{array}{l}<1: 80 \\
>1: 80\end{array}$ & $\begin{array}{l}63 / 96(66) \\
32 / 92(35)\end{array}$ & $<.001$ \\
\hline (Indirect HA) $^{\dagger}$ & $\begin{array}{l}<1: 64 \\
>1: 64\end{array}$ & $\begin{array}{l}19 / 29(66) \\
54 / 139(39)\end{array}$ & $<.01 ;$ \\
\hline $\begin{array}{l}\text { Cross-reactive antibodies } \\
\text { (Indirect HA) }\end{array}$ & $\begin{array}{l}<1: 80 \\
>1: 80\end{array}$ & $\begin{array}{c}67 / 112(60) \\
6 / 39(15)\end{array}$ & $<.01$ \\
\hline
\end{tabular}

NOTE. Adapted from [8] and [11]. Abbreviations: IF = immunofluorescence; $\mathrm{HA}=$ hemagglutination.

* Type-specific antibodies are directed to the side chains of gram-negative bacterial outer-membrane lipopolysaccharides (LPS) called $O$ antigens, which are strain-specific.

$\dagger$ Indirect hemagglutination measures mainly IgM.

$\ddagger$ Cross-reactive antibodies are directed to the core region of LPS, which is highly conserved among gram-negative bacteria. LPS of the rough mutant Re of Salmonella minnesota was used as the antigen to detect antibodies to the core.

specific $\mathrm{O}$ side chains into the common core region because they lack the specific enzymes. Thus, the LPS of these mutants is composed only of lipid A and various core sugars. Two rough strains have been widely used to detect cross-reactive antibodies in patients; one of these is the Re mutant of Salmonella minnesota used by McCabe et al. [8] and the other is the J5 mutant of Escherichia coli 0111 used by Pollack et al. $[9,10]$. McCabe et al. [8] have shown that the survival of patients with gram-negative bacteremia was related to their titers of antibody to the core glycolipid present at the onset of bacteremia (table 2). The correlation that was found between antibody to core glycolipid and survival was independent of the levels of O-specific IgG antibody [11]. In addition, these authors found that antibody to $O$-specific antigens also correlated significantly with outcome, although less strikingly than the antibody to core glycolipid. In their first report [8], McCabe et al. determined antibody titers by indirect hemagglutination with LPS extracted from the infecting bacteria; this method measures mainly IgM antibodies. Subsequently, when measuring antibodies in the same sera by immunofluorescence, Zinner et al. [11] found that survival was significantly related to the 
titers of $\mathrm{O}$-specific IgG antibodies but not to the titers of O-specific IgM antibodies.

Studies by Pollack et al. $[9,10]$ have concentrated on patients with Pseudomonas aeruginosa septicemia. In accordance with the observation by McCabe et al. [8], Pollack and Young [9] observed a similar relation between survival of patients with $P$. aeruginosa septicemia and titers of $\mathrm{O}$-specific antibodies measured by indirect hemagglutination with purified $P$. aeruginosa LPS. A similar correlation was subsequently found between antibodies to core glycolipid measured by ELISA and outcome from $P$. aeruginosa septicemia (table 3) [10]. Both IgG and IgM antibodies to core glycolipid were associated with a lower mortality rate. In a multivariate analysis strain-specific hemagglutinating antibody levels were the best predictor of outcome, followed by $\operatorname{IgM}$ and then IgG antibodies to core glycolipid.

These observations suggested, therefore, that strain-specific as well as cross-reactive antibodies may protect patients from severe septic shock or death due to gram-negative bacteria. Thus passive immunotherapy in critically ill patients may be of benefit. Two approaches to passive immunotherapy have been taken. The first consists of the administration of purified immunoglobulins prepared from pooled plasma from a large number of donors and containing a wide range of strain-specific antibod-

Table 3. Relation of survival to antibody levels in 43 patients with Pseudomonas aeruginosa septicemia.

\begin{tabular}{lccc}
\hline $\begin{array}{l}\text { Antibody measured } \\
\text { (method of detection) }\end{array}$ & $\begin{array}{c}\text { Antibody } \\
\text { levels* }\end{array}$ & $\begin{array}{c}\text { Percent } \\
\text { survival }\end{array}$ & $\begin{array}{c}P \\
\text { value }\end{array}$ \\
\hline $\begin{array}{l}\text { Type-specific antibodies } \dagger \\
\text { (Indirect HA) }\end{array}$ & & & \\
& $>1: 32$ & 48 & .03 \\
& $>1: 32$ & 85 & \\
$\begin{array}{l}\text { Cross-reactive antibodies } \\
\text { IgG Antibody to J5 core }\end{array}$ & & & \\
$\quad$ glycolipid (ELISA) & $<10$ & 14 & $<.001$ \\
& $>10$ & 79 & \\
IgM Antibody to J5 core & & & \\
$\quad$ glycolipid (ELISA) & $<30$ & 44 & .01 \\
\hline
\end{tabular}

NOTE. Adapted from [9] and [10]. Abbreviation: HA = hemagglutination.

* Antibody levels are expressed as titers for type-specific antibodies and $\mu \mathrm{g} / \mathrm{ml}$ for cross-reactive antibodies.

$\dagger$ For explanations of type-specific and cross-reactive antibodies, see footnotes to table 2 . In this experiment lipopolysaccharide of the rough mutant $\mathrm{J} 5$ of Escherichia coli 0111 was used as antigen to measure antibodies to the core glycolipid.

¥ Indirect hemagglutination measures mainly IgM. ies. The second approach is the administration of cross-reactive antibodies.

\section{Rationale for the Use of Purified Intravenous Immunoglobulin Preparations}

Advantages of immunoglobulin preparations for intravenous use. Since the 1940 s, cold alcohol precipitation has been used for separating the antibody $(\gamma$-globulin) fraction of plasma [12]. This procedure yields $90 \%$ IgG with traces of IgA and IgM. These preparations contain aggregate forms of IgG that activate the complement system when administered intravenously and cause a high incidence of untoward reactions; thus the intramuscular administration of these preparations is mandatory. The maximum admissible dose by this route is $1.5-3 \mathrm{~g}$ per injection, and absorption is slow, precluding the use of these immunoglobulin preparations for the treatment of acute severe infections.

New techniques were developed in the late 1970s that allow iv administration of immunoglobulin. Various preparations are now commercially available, so that high doses of IgG may be administered in a small volume with immediate bioavailability. Because modern blood banks utilize mainly the cellular components of blood, the supply of plasma derivatives is abundant. Plasmas from thousands of donors are pooled for preparing purified immunoglobulin. Since the immunoglobulin preparation contains the antibodies present in the pool, it has high titers of antibody against hundreds of bacterial strains [13-15]. Immunoglobulins for intravenous administration (IVIG) have a good opsonic activity against various bacteria $[16,17]$ and have been shown to be protective against various infections in animals [15, 18-23]. The storage in lyophilized form makes IVIG available on a large scale. These developments produced renewed interest in the utilization of purified immunoglobulin for the prophylaxis and treatment of bacterial infections in critically ill patients [24].

Controversial aspects of IVIG preparations. There are some disadvantages of IVIG preparations. First, the preparation procedures may alter some IgG functions. The precipitation with ethanol inducès a partial denaturation of the immunoglobulin, which leads to formation of aggregates and complement activation. Additional procedures are necessary to remove the aggregates and to decrease the anticomplementary activity. Treatments with pepsin, plas- 
min, $\beta$-propiolactone, polyethylene glycol, sulfonation, reduction and alkylation; or treatment with small doses of pepsin at low pH (e.g., pH 4) may be used [25]. These procedures induce modifications of the immunoglobulin molecules in addition to those induced by the ethanol precipitation. The functional importance of these changes in the clinical setting is not known, but in vitro observations have suggested that some of these procedures may alter the opsonic activity of the immunoglobulin [16].

A second disadvantage of the use of IVIG preparations is that some patients lack immune factors other than IgG. Low levels of plasma IgG in critically ill patients may be due to conditions such as increased catabolism, capillary leakage, dilution by resuscitation regimens, and decreased synthesis due to lack of nutritional support [26]. However, complex immunologic alterations have been observed after conditions such as surgery, accidental injuries, or burns. Neutrophil functions, cell-mediated immunity, complement factors, plasma fibronectin, and IgM levels may be altered. The relative importance of these host-defense defects in promoting severe infections in critically ill patients is not known. Administration of IgG by purified IVIG may therefore bring only a partial benefit, if any at all, to these patients.

The third controversial aspect is that large amounts of IVIG may block the reticuloendothelial system, a property that has been used to reduce the clearance of circulating platelets in refractory idiopathic thrombocytopenia [27]. In patients with infections such a blockade could be detrimental because of a decrease in the clearance of circulating microbial pathogens [28].

For all these reasons carefully planned and conducted clinical trials appear mandatory for exploring the efficacy of IVIG in the treatment of infections in critically ill patients.

\section{Clinical Studies of IVIG Administration in Critically III Patients}

Neonates. Neonates, particularly when born before term, are susceptible to bacterial infections because they have immature immune defenses. Neutrophils may exhibit defects in chemotaxis, phagocytosis, and killing. Complement levels in newborns are lower than those in infants and adults. Immunoglobulins in neonates consist mainly of IgG transmitted by the mother through the placenta at the end of the pregnancy. Premature babies have a deficiency of IgG because only a small amount of antibody crosses the placenta early in pregnancy [29].

Group B streptococci are a major cause of neonatal sepsis and meningitis [30]. Opsonization and killing of these encapsulated bacteria are antibody dependent. Undetectable or low levels of typespecific antibodies to group B streptococci correlate with susceptibility to infection with this organism [31]. Various IVIG preparations have been shown to. have functional activity against group B streptococci in vitro and in animal experiments [20-23]. These findings suggest, therefore, that IVIG could be effective when administered prophylactically to highrisk neonates or therapeutically to neonates with established infections.

Several studies aimed at determining the efficacy of im-administered immunoglobulin for preventing infections in neonates have failed to show consistent benefits [32-34]. Another prophylactic approach consisting of the administration of IVIG to mothers with high-risk pregnancies was found to be unfeasible because very large amounts of IVIG were necessary to cause only a slight increase of IgG levels in the offspring $[35,36]$. Studies using high doses of IVIG administered to neonates have shown that it may significantly increase their levels of $\mathrm{IgG}$, including group B streptococcal-specific IgG [35, 37]. However, to the best of our knowledge, no trial of IVIG for prophylaxis has been performed recently.

A possible protective effect of the therapeutic administration of immunoglobulins to newborns infected with group B streptococci was suggested by a retrospective study showing an improved survival of infants who received blood containing typespecific antibody to the infecting group B Streptococcus [38]. In addition, an increased survival of infants receiving blood transfusions compared with those not receiving transfusions [39] was reported in another retrospective study. Clearly these findings warrant confirmation by prospective studies.

Sidiropoulos et al. [40] have treated 82 neonates thought to have bacterial infections - either with antibiotics alone or with antibiotics and a pH 4-treated IVIG preparation (0.5-1.0 g per day for six days). Forty-seven infants had clinical signs of sepsis, but the diagnosis was not confirmed by positive cultures of blood and CSF. Of the 35 patients with positive cultures, 20 (nine with $E$. coli, five with Streptococcus species, three with Klebsiella species, two with anaerobes, and one with Aerobacter species infec- 
tions) received antibiotics and IVIG, and 15 (five with $E$. coli, three with Streptococcus species, two with Klebsiella species, two with Staphylococcus aureus, one with Listeria species, one with Serratia species, and one with Pseudomonas species infections) received antibiotics alone. Two of the 20 patients treated with IVIG died, compared with four of the 15 control patients; this was not a statistically significant difference. Within the subgroup of infants born prematurely, one of 13 treated with IVIG and four of nine control patients died, a difference that is not statistically significant either by two-tailed $\chi^{2}$ test with Yates' correction or by Fisher's exact test (the authors found a $P$ value of $<.05$ ). This study, unfortunately, did not provide unequivocal results because it was not blinded, the number of cases was small, and the differences were not statistically significant.

Burned patients. The extensively burned patient is at increased risk of infections as a result of impairment of host-defense mechanisms. P. aeruginosa is particularly troublesome in these patients as it frequently colonizes burned skin. Active immunization with $P$ aeruginos $a$ vaccine has been studied for almost 20 years. These studies have been reviewed elsewhere [41].

Serum IgG concentration in burned patients is decreased and remains low in fatal cases [42, 43]. Administration of immunoglobulin by the intramuscular route has been attempted with variable results. Kefalides et al. [44] found a significant decrease in the septic complications of burns by the im administration of immunoglobulin. However, the group of controls had a greater incidence of infectious complications than would be expected and, in addition, all patients were involved in multiple studies. Stone et al. [45] could not demonstrate a benefit from the im administration of a similar amount of immunoglobulin in 100 patients, a failure attributed to the minute amounts of antibodies to $P$. aeruginosa contained in the immunoglobulin preparation. Subsequent investigators have used im administration of hyperimmune immunoglobulin against $P$. aeruginosa with apparently favorable results. Unfortunately, Alexander and Fisher [46] used a historical control group. Thus their results should be viewed with caution. Jones et al. [47] studied patients in a hospital in India. Topical administration of antibacterial agents was not used, patients were not placed in a protective environment, and the antibiotics used for treating infections were ampicillin and penicillin,
Thus there is a question of the relevance of this nonblinded study to burned patients in Western Europe and North America.

There have been no reports of clinical trials in which either standard or hyperimmune IVIG preparations were administered to burned patients for therapeutic or prophylactic purposes. Standard and $P$ aeruginosa-hyperimmune IVIG preparations have shown good immunologic and opsonic activity in vitro and were protective in animal experiments [48-51]. In a preliminary report Shirani et al. [52] described the maintenance of normal serum IgG levels in burned patients by the infusion of $500 \mathrm{mg}$ IVIG/kg twice a week.

Postsurgical and trauma patients. Prophylactic use of IVIG. There have been two trials of IVIG for prophylaxis in patients after surgery or trauma [53, 54]. Duswald et al. in Germany [53] studied $\beta$-propiolactone-treated IVIG. They randomized, in a nonblinded fashion, 150 patients who had undergone elective abdominal or thoracic surgery into three groups: a control group receiving no immunoglobulin, a group receiving a low dose of IVIG (2.5 $\mathrm{g}$ after surgery), and a group receiving a high dose of IVIG $(10 \mathrm{~g}$ after surgery and $10 \mathrm{~g}$ the following day). These investigators further divided the patients into low-risk (following clean and clean-contaminated operations) and high-risk (following contaminated and dirty operations) groups. A decrease in the number of local infections in the low-risk group of patients was observed after high-dose IVIG (six of 28 patients developed local infections in the highdose IVIG group, compared with 15 of 29 in the lowdose and 15 of 33 in the control groups). No difference in the incidence of local infections was seen among high-risk patients. In the patients with infections lasting for more than 14 days, the authors reported a significant decrease in the incidence of "systemic repercussions" of the focal infections, an ill-defined condition. Unfortunately, this study suffers from deficiencies, such as the absence of blind evaluation of outcome, the lack of microbiologic documentation of infections, and the unreported death rate; thus a strict evaluation of the results is difficult.

Glinz et al. in Switzerland [54] performed a double-blind randomized study in which 150 severely injured patients received either very high doses of a $\mathrm{pH} 4$-treated IVIG preparation (36 $\mathrm{g}$ in three equal doses administered on days 0,5 , and 12 after trauma) or the same volume of a placebo $(0.03 \%$ albumin 
solution). The two groups were well balanced for patient characteristics and injury-severity scores. The occurrence of septicemia and local infections was similar except for a lower incidence of pneumonia in the IVIG group ( 28 cases) compared with the placebo group (43 cases). The bacteriologic documentation of pneumonia was insufficient, however, and the clinical and radiologic severity of the pneumonic episodes was not reported. The decrease in the incidence of pneumonia in the IVIG group did not appear to have a major impact on clinical outcome, since the number of days with ventilatory assistance, the overall lethality, and the lethality caused by infections were not decreased. A possible benefit of IVIG was that IVIG-treated patients seemed to need antibiotics less often than control patients. The duration of stay in the intensive care unit was not analyzed. Thus, no major impact of high-dose IVIG given prophylactically was observed in this study of critically injured patients.

Postsurgical and trauma patients - therapeutic use of IVIG. Just et al. [55] have tested an IVIG preparation containing a mixture of $\mathrm{IgG}(30 \mathrm{mg} / \mathrm{ml}), \mathrm{IgM}$ $(5 \mathrm{mg} / \mathrm{ml})$, and $\operatorname{IgA}(7.8 \mathrm{mg} / \mathrm{ml})$. The method of preparation of this antibody mixture was not described. One hundred four infected postoperative patients in an intensive care unit were randomized in a nonblinded manner to receive either antibiotics combined with IVIG (100 ml four times within 36 $\mathrm{hr}$ ) or antibiotics alone. The patients were entered into four different risk groups according to a preoperative classification established by the authors. The commonest infections observed during the study were pneumonia, septicemia, peritonitis, and wound sepsis. The diagnoses were well balanced between the two treatment groups, but the severity of the infections was not described. Differences in the microorganisms recovered from the infected sites were apparent between the two treatment groups; $E$. coli and Haemophilus influenzae were commoner in the IVIG treatment group, while $S$. aureus, $P$. aeruginosa, Enterobacter cloacae, and other gram-negative bacteria were commoner in the control group. The mortality attributed to infections and the overall mortality did not differ between the IVIG and the control groups (seven of 50 vs. 11 of 54 and 25 of 50 vs. 22 of 54, respectively). In patients preoperatively classified as high risk, the durations of respiratory support and stay in the intensive care unit were significantly shorter in the IVIG treatment group than in controls (5.5 vs. 12.7 days and 14.8 vs. 21.5 days, respectively). These differences were not found in the three other categories of surgical-risk groups. The beneficial effect of IVIG observed in this study needs confirmation in a double-blind trial mainly because the major impact of IVIG in that study was on the duration of stay in the intensive care unit, a criterion that may be biased by the knowledge of the treatment group.

\section{Conclusions: Use of IVIG in the Critically III Patient}

The clinical trials reported above did not demonstrate serious adverse effects of the administration of IVIG to neonates as well as to burned, postsurgical, and trauma patients. In vitro and animal experiments have shown a protective efficacy of IVIG preparations against various bacterial infections. Unfortunately, the results of trials in humans that are presently available are subject to criticism because of problems in study designs. Overall, the benefits reported were moderate. No major impact on mortality has been observed. Further well-designed studies are needed to investigate the cost-effectiveness of IVIG administration to critically ill patients. This question is important since IVIG preparations are very expensive and many patients are candidates for receiving them. Currently, the role of IVIG in the management of critically ill patients is still largely ignored.

\section{Clinical Studies of Core-Glycolipid Antiserum or Plasma for Treatment and Prophylaxis of Gram-Negative Bacteremia}

As mentioned earlier the poor outcome of gramnegative bacterial infections in humans is attributed to the LPS, the toxicity of which is not prevented by antibiotics. Studies in animals have shown that immunization with smooth gram-negative bacteria protects from many of the adverse effects of endotoxin and gram-negative bacterial infections [56, 57]. However, antibodies to complete LPS are directed primarily against the immunodominant, species-specific oligosaccharide side chains and protect mainly against the immunizing bacterial strain. Since thousands of antigenically different strains may cause infections in humans, it is difficult to obtain broadly protective antibodies to a mixture of side chains.

In contrast to oligosaccharide side chains, the central part of the LPS molecule - the core glycolipid, 
which is responsible for LPS toxicity - shows little strain variation. Immunization with bacteria whose LPS contains only core-glycolipid determinants, such as various rough mutants of gram-negative bacteria, has been shown to protect animals from a wide variety of gram-negative bacteria [58-63] and endotoxins [64-66]. In addition, as previously mentioned, retrospective studies in humans have shown that levels of antibody to core glycolipid correlated with survival of patients from bacteremia due to various gram-negative bacilli $[8,11]$ and to $P$. aeruginosa [10]. These observations in animals and humans have prompted clinical studies with antiserum obtained by immunizing volunteers with the rough mu$\tan t E$. coli $\mathrm{J} 5$. This preparation has been tested in double-blind, randomized, controlled trials for therapy in patients with established gram-negative bacteremia and for prophylaxis against gram-negative bacillary infections in high-risk surgical patients.

Treatment of gram-negative bacteremia. Ziegler et al. [67] have studied the cross-protection afforded by antisera collected from humans after immunization with $E$. coli J5. Serum was withdrawn from healthy volunteers before (control serum) and two weeks after immunization with $\mathrm{J} 5$ vaccine (J5 antiserum). In a randomized double-blind trial, these investigators administered test serum to 304 patients with clinically suspected severe gram-negative bacteremia. The diagnosis was subsequently confirmed microbiologically in 212 patients $(70 \%) ; 109$ of these patients received control serum and 103 received immune serum. Characteristics of patients such as age, sex, race, severity of underlying diseases, and treatments received were well balanced between the two groups. Also well balanced were conditions with a poor prognosis, such as gram-negative bacillary pneumonia, pseudomonas bacteremia, hypotension, or profound septic shock. The most frequent sources of bacteremia were abdominal infections ( 33 in the control group and 27 in the $\mathrm{J} 5$ group), neutropenia (41 and 29, respectively), soft tissue and mucous membrane infections ( 25 and 23 ), pneumonia (15 and 15 ), and genitourinary tract infections (18 and 14). The most frequent bacterial isolates were $E$. coli ( 35 and 35, respectively), P. aeruginosa (20 and 24), and Klebsiella species (16 and 13). The number of deaths in the bacteremic patients was $42(39 \%)$ of 109 in controls and $23(22 \%)$ of 103 in recipients of J5 antiserum $(P=.011)$. In those patients with profound shock who needed treatment with vasopressors for more than six hours, mortality was reduced from 30
$(77 \%)$ of 39 in controls to $18(44 \%)$ of 41 in recipients of J5 antiserum $(P=.003)$. The protection afforded by $\mathrm{J} 5$ antiserum was the most striking in neutropenia and soft tissue infections, and was less apparent in abdominal infections, in which the mortality rate was $39 \%$ in controls and $33 \%$ in recipients of J5 antiserum.

Overall, this study established that the administration of $\mathbf{J} 5$ antiserum decreased the mortality rate by one-half in patients with established gramnegative bacteremia, even when profound septic shock was already present.

Prophylaxis of gram-negative bacillary shock in surgical patients. In view of the success of J5 antiserum in the treatment of patients with established gram-negative bacteremia or shock, a randomized, double-blind trial of plasma containing antibodies to J5 (anti-J5 plasma) for prophylaxis was performed in surgical patients at high risk of acquiring gramnegative bacterial infections [68]. Since JS antiserum had apparently not improved the survival of patients with gram-negative bacteremia originating from abdominal infections in the therapeutic trial, a major purpose of the trial for prophylaxis was to test whether anti-J5 plasma would prevent the establishment of gram-negative bacteremia in patients undergoing complicated abdominal surgery, a condition with a high risk of severe gram-negative bacillary infections. The other purpose of this trial was to test the prophylactic efficacy of anti-J5 plasma in other surgical injuries with a high incidence of infectious complications, such as severe multiple trauma and pulmonary surgery in high-risk patients. Immunization of volunteers was performed as in the previous study, but plasma was used instead of serum because plasmapheresis allowed the collection of larger volumes from the volunteers. Patients suitable for the study were randomized separately in each category of surgery. Each patient received one unit of test plasma ( $4 \mathrm{ml} / \mathrm{kg}$ ) during the first $24 \mathrm{hr}$ after admission to the surgical intensive care unit and booster units every five days as long as the patient remained severely ill in the intensive care unit. Additional test plasma was given if septic shock developed because it was hypothesized that antibodies to core glycolipid might be depleted in this condition.

Two hundred sixty-two patients were included in the study and observed daily as long as they remained in the intensive care unit and for two weeks thereafter. The analysis of the results showed that anti-J5 plasma did not prevent the acquisition of new focal 
gram-negative bacterial infections, nor did it prevent shaking chills and febrile spikes associated with such infections. In contrast, anti-J5 plasma was very effective in preventing the severe consequences of gram-negative bacterial infections, i.e., shock and death. This protective ef fect was most striking in patients who had undergone abdominal surgery, in whom the majority of the severe gram-negative bacillary infections occurred during the study. Indeed, among this latter category of patients, shock occurred in 13 of 83 control-plasma recipients and in only two of 71 anti-J5-plasma recipients $(P=.006)$, and subsequent death occurred in nine of 83 and one of $71(P=.017)$, respectively (table 4$)$. In the two other surgical categories, fewer severe gram-negative bacterial infections occurred, and the efficacy of anti-J5 plasma was not demonstrable separately in each category. When all categories of patients were considered together, the protection was significant: gram-negative bacillary shock occurred in 15 of 136 control-plasma recipients and in six of 126 anti-J5plasma recipients $(P=.049)$ and subsequent death occurred in nine of 136 and two of 126 patients, respectively $(P=.033)$. Very striking was that the incidences of shock and death due to gram-positive bacteria or fungi were not different between the two study groups, an observation demonstrating that the effect of anti-J5 plasma was specifically directed against gram-negative bacteria.

The results of this clinical study strengthen, therefore, those of previous studies in animals on the mode of action of antibodies to core glycolipids. The latter studies have suggested that such antibodies may act primarily as neutralizing (antitoxic) antibodies, not as opsonizing antibodies [69]. Indeed, anti$\mathrm{J} 5$ plasma in our study did not prevent the acquisition of new gram-negative bacterial infections; it only prevented their toxic consequences.

Discussion and future areas of research. The current view on the mechanism of protection afforded by $\mathrm{J} 5$ antiserum or anti-J 5 plasma is that they neutralize the harmful effects of endotoxins by means of cross-reactive antibodies to core glycolipid. This view is supported by previous animal experiments showing cross-protection from $\mathrm{J} 5$ antiserum not only against whole gram-negative bacteria but also against purified endotoxins [59-66]. Furthermore, the results of retrospective studies in humans have demonstrated a significant correlation between titers of antibody to core glycolipid and survival of patients with bacteremia due to various gram-negative
Table 4. Prevention of shock and death due to gramnegative bacteria with anti-J5 plasma administered prophylactically to surgical patients at high risk of infection.

\begin{tabular}{|c|c|c|c|}
\hline \multirow{2}{*}{$\begin{array}{l}\text { Category of surgery, } \\
\text { outcome }\end{array}$} & \multicolumn{2}{|c|}{$\begin{array}{l}\text { No. of patients } \\
\text { receiving indicated } \\
\text { type of plasma }\end{array}$} & \multirow[b]{2}{*}{$P$ value } \\
\hline & Control & Anti-J5 & \\
\hline Abdominal & 83 & 71 & \\
\hline Infection* & 21 & 15 & NS \\
\hline Shock & 13 & 2 & .006 \\
\hline Death & 9 & 1 & .017 \\
\hline All categories $\dagger^{\dagger}$ & 136 & 126 & \\
\hline Infection* & 33 & 29 & NS \\
\hline Shock & 15 & 6 & .049 \\
\hline Death & 9 & 2 & .033 \\
\hline
\end{tabular}

NOTE. Adapted from [68]. Abbreviation: NS = not significant.

* Infections were pneumonia and intraabdominal and mediastinal infections.

$\dagger$ The categories of surgery other than abdominal surgery were: multiple trauma ( 31 patients in control and 34 in anti-J5 group) and pulmonary surgery in high-risk patients (22 patients in control and 21 patients in anti-J5 group).

bacilli (table 2), and $P$. aeruginosa (table 3). Lastly, in the prospective studies reported above, J5 antiserum and anti-J5 plasma have been shown to improve survival of patients with established gram-negative bacteremia [67] and specifically to prevent the occurrence of septic shock and death due to gram-negative, but not gram-positive, bacteria [68].

Such a mechanism of cross-protection has not been definitely proved in clinical trials, however. Indeed, in the trials of $\mathrm{J} 5$ antiserum for both therapeutic and prophylactic use, it has been difficult, for several reasons, to clearly relate outcome with levels of antibody to core glycolipid. The first reason is that many sera from nonimmunized volunteers as well as sera from recipient patients had naturally occurring antibodies to $\mathrm{J} 5 \mathrm{LPS}$, sometimes in very high titers. The second reason is that $\mathbf{J} 5$ vaccine is a weak immunogen and, in volunteers, induced only a threeto five-fold increase in titers of antibody to J5 LPS ([67] and authors' unpublished data). For these two reasons there has been a great overlap in titers of antibody to J5 LPS between immune and control serum (or plasma) administered to patients. The third reason is that the administration of $4 \mathrm{ml}$ of immune plasma $/ \mathrm{kg}$ to the patients in the prophylactic trial produced only a slight, sometimes undetectable, increase in levels of antibody to J5 LPS (authors' unpublished data). 
For these reasons, although the clinical data clearly showed a benefit from the administration of $\mathrm{J} 5$ antiserum or anti-J5 plasma as compared with a similar volume of the nonimmune preparation, the relation between levels of antibody to J5 LPS administered to the patients and improved outcome has been weak. Indeed, Ziegler et al. [67] measured antibodies to J5 LPS by indirect hemagglutination. Overall, they could not relate protection to titers in antiserum administered, regardless of the immunologic status of the donor. They could only show a protective trend with respect to J5-antibody titers in patients in profound gram-negative bacterial shock. In this group the mortality rate in 53 patients given serum with hemagglutinating antibody titers of $>1: 8$ was $53 \%$, as compared with $74 \%$ in 27 patients given serum with titers of $\leqslant 1: 8(P=.07)$.

In the study of prophylactic use of anti-J5 plasma in surgical patients [68], a correlation was found between the number of deaths due to gram-negative bacillary infections and levels of IgG or IgM antibody to J5 LPS in plasma administered to the patients (table 5). However, a multivariate analysis demonstrated that the best predictor of the protective power of the plasma was not the levels of $\mathrm{IgG}$ or IgM antibodies to J5 LPS present in the plasma, but whether the plasma was from immune or control volunteers (authors' unpublished data). Thus, both prospective trials have not convincingly demonstrated that the protective activity of J5 antiserum or anti-J5 plasma was due to antibodies to J5 LPS, as measured by ELISA or indirect hemagglutination.

At the present time, in addition to the hypothesis attributing cross-protection to antibodies to J5 LPS, three alternatives might be proposed to explain the beneficial effects of immunization by heat-killed $E$. coli $\mathrm{J} 5$ cells. The first is that protection might be mediated by humoral factors other than antibody. The $\mathrm{J} 5$ vaccine may nonspecifically increase some unrecognized acute-phase reactants capable of neutralizing LPS or altering its metabolism [70-72]. The second possibility is that passive protection, as seen after immunization with $E$. coli $\mathrm{J} 5$, might be due to a nonspecific polyclonal antibody response of the immunized volunteers, a phenomenon known to occur after injections of endotoxins from both smooth and rough bacteria $[73,74]$. To investigate this hypothesis, we tested 12 pairs of human plasma, sampled before and after immunization with $\mathrm{J} 5$ vaccine, against LPSs extracted from seven unrelated smooth gram-negative bacteria. A modest polyclonal in-
Table 5. Relation of death due to infections with gramnegative bacteria to levels of antibody to J5 lipopolysaccharide (LPS) in plasma administered prophylactically to surgical patients.

\begin{tabular}{lccc}
\hline $\begin{array}{l}\text { Level of antibody* } \\
\text { (units/ml) }\end{array}$ & $\begin{array}{c}\text { No. of } \\
\text { patients }\end{array}$ & $\begin{array}{c}\text { No. of } \\
\text { deaths }\end{array}$ & $P$ value \\
\hline IgG antibody to J5 LPS & & & \\
$\quad \leqslant 50$ & 133 & 8 & $.057^{\dagger}$ \\
$>50$ & 129 & 2 & \\
IgM antibody to J5 LPS & & & \\
$\quad \leqslant 50$ & 183 & 10 & $.02^{\dagger}$ \\
$>50$ & 71 & 0 & \\
\hline
\end{tabular}

* Measured by ELISA.

$\dagger$ A multivariate analysis revealed that whether the plasma was immune or control was a better predictor of outcome than the levels of antibody to J5 lipopolysaccharide (IgG or IgM).

crease of IgG and/or IgM antibodies was observed in only eight of the pairs. In these pairs the mean increase in titers of antibody against the seven smooth LPSs ranged from 1.1-fold to 2.2-fold (M. Pollack and J.D. Baumgartner, unpublished data). This increase seems modest if it is to fully account for the broad protection afforded by plasma after immunization with $E$. coli J5. Furthermore, if either one or both of the two mechanisms mentioned above were operative in the protection afforded after administration of anti-J5 plasma, it would not account for the experimental observation that only very limited cross-protection is observed after immunization with smooth bacteria.

A third, more likely explanation is that protection might be due to cross-reactive antibodies to core glycolipid that are not accurately measured when using J5 LPS as the test antigen. To investigate this latter possibility, we immunized rabbits with $E$. coli $\mathbf{J} 5$ and then examined the reactivity of the rabbit serum against various strains of gram-negative bacteria. Adsorption of highly diluted rabbit J5 antiserum with various smooth, gram-negative bacteria reduced by $<35 \%$ the levels of antibody to J5 LPS measured by ELISA [75]. This decrease demonstrated that most antibodies to J5 LPS were directed against determinants that are specific for the J5 LPS molecule and presumably associated with core sugars. When we measured antibody to $S$. minnesota Re LPS, which in contrast to J5 LPS contains no core structures other than lipid A and 2-keto-3-deoxyoctonate (KDO), we found, by adsorption with $S$. minnesota Re or by direct ELISA, that $<5 \%$ of the total antibodies to J5 LPS was directed against 
Re LPS in serum from rabbits immunized with $E$. coli J5. This might not, however, reflect the actual proportion of antibodies to lipid A and KDO since antibody directed against lipid determinants might have a lower affinity than antibody directed against oligosaccharides of the core, thus preventing the detection of the former by ELISA. Further studies are needed to determine precisely which epitope(s) (possibly the lipid A or part of it) on the complex J5 LPS molecule may be responsible for eliciting cross-protective antibody.

In summary, if protection afforded by serum or plasma collected from volunteers after immunization with $E$. coli $\mathrm{J} 5$ is mediated by cross-protective antibodies to LPS, two important questions remain to be definitively answered. One is the determination of the epitope(s) of the LPS core molecule that is the relevant antigen(s) for eliciting the best crossreactive antibodies. The answer to this question is crucial at the present time because it will permit the screening of blood donors for the preparation of hyperimmune purified immunoglobulins, as well as the production of monoclonal antibodies. The second question still unresolved is which type of antibodies - IgG, IgM, or both - is most protective. The resolution of this question is important if hyperimmune IVIG preparations must be used, since these preparations contain almost exclusively IgG. Only after the resolution of these two questions will it be possible to test, in well-controlled clinical trials, the efficacies of hyperimmune IVIG preparations and monoclonal antibodies in the treatment of critically ill patients.

\section{References}

1. Behring E, Boer A, Kossel $\mathrm{H}$. Zur behandlug diphtheriekranker menschen mit diphtherieheilserum. Dtsch Med Wochenschr 1893;17:389-93;18:415-8;23:543-7

2. Root RK, Ryan JL. Humoral immunity and complement. In: Mandell GL, Douglas RG Jr, Bennett JE, eds. Principles and practice of infectious diseases. 2nd ed. New York: Wiley, 1985:31-57

3. Caplan ES, Hoyt N. Infection surveillance and control in the severely traumatized patient. Am J Med 1981;70:638-40

4. Machiedo GW, Loverme PJ, McGovern PJ Jr, Blackwood JM. Patterns of mortality in a surgical intensive care unit. Surg Gynecol Obstet 1981;152:757-9

5. Maki DG. Nosocomial bacteremia. An epidemiologic overview. Am J Med 1981;70:719-32

6. Kreger BE, Craven DE, Carling PC, McCabe WR. Gramnegative bacteremia. III. Reassessment of etiology, epidemiology and ecology in 612 patients. Am J Med 1980;68: $332-43$
7. Shenep JL, Mogan KA. Kinetics of endotoxin release during antibiotic therapy for experimental gram-negative bacterial sepsis. J Infect Dis 1984;150:380-8

8. McCabe WR, Kreger BE, Johns M. Type-specific and crossreactive antibodies in gram-negative bacteremia. $N$ Engl J Med 1972;287:261-7

9. Pollack M, Young LS. Protective activity of antibodies to exotoxin A and lipopolysaccharide at the onset of Pseudomonas aeruginosa septicemia in man. J Clin Invest 1979;63:276-86

10. Pollack M, Huang AI, Prescott RK, Young LS, Hunter KW, Cruess DF, Tsai C-M. Enhanced survival in Pseudomonas aeruginosa septicemia associated with high leveis of circulating antibody to Escherichia coli endotoxin core. J Clin Invest 1983;72:1874-81

11. Zinner SH, McCabe WR. Effects of IgM and IgG antibody in patients with bacteremia due to gram-negative bacilli. J Infect Dis 1976;133:37-45

12. Cohn EJ, Oncley JL, Strong LE, Hughes WL Jr, Armstrong SH Jr. Chemical, clinical, and immunological studies on the products of human plasma fractionation. 1 . The characterization of the protein fractions of human plasma. $\mathbf{J}$ Clin Invest 1944;23:417-32

13. Römer J, Morgenthaler J-J, Scherz R, Skvaril F. Characterization of various immunoglobulin preparations for intravenous application. I. Protein composition and antibody content. Vox Sang 1982;42:62-73

14. Rousell RH, Collins MS, Dobkin MB, Louie RE, Roby RE, Sweet BH. Antibody levels in reduced/alkylated intravenous immune globulin. Am J Med 1984;76(3A):40-5

15. Pollack M. Antibody activity against Pseudomonas aeruginosa in immune globulins prepared for intravenous use in humans. J Infect Dis 1983;147:1090-8

16. van Furth R, Leijh PC, Klein F. Correlation between opsonic activity for various microorganisms and composition of gammaglobulin preparations for intravenous use. J Infect Dis 1984;149:511-7

17. Hill HR, Augustine NH, Shigeoka AO. Comparative opsonic activity of intravenous gamma globulin preparations for common bacterial pathogens. Am J Med 1984;76(3A):61-6

18. Collins MS, Dorsey JH. Comparative anti-Pseudomonas aeruginosa activity of chemically modified and native immunoglobulin $\mathrm{G}$ (human), and potentiation of antibiotic protection against Pseudomonas aeruginosa and group B Streptococcus in vivo. Am J Med 1984;76(3A):155-60

19. Collins MS, Roby RE. Protective activity of an intravenous immune globulin (human) enriched in antibody against lipopolysaccharide antigens of Pseudomonas aeruginosa. Am J Med 1984;76(3A):168-74

20. Vogel LC, Kretschmer RR, Padnos D, Gotoff SP. Passive immunizations against group B streptococci with human gamma globulin in the chick embryo [abstract]. Pediatr Res 1978;12:500

21. Santos JI, Shigeoka AO, Rote NS, Hill HR. Protective efficacy of a modified immune serum globulin in experimental group B streptococcal infection. J Pediatr 1981;99:873-9

22. Fischer GW, Hunter KW, Wilson SR. Modified human immune serum globulin for intravenous administration: in vitro opsonic activity and in vivo protection against group $B$ streptococcal disease in suckling rats. Acta Padiatr Scand 1982;71:639-44 
23. Christensen KK, Christensen P, Duc G, Hitzig WH, Lindén V, Müller B, Seger RA. Human IgG antibodies to carbohydrate and protein antigens in mouse protection tests with group B streptococci. Pediatr Res 1984;18:478-82

24. Nydegger UE. Pathophysiological aspects of bacterial infection: towards a rationale for prophylaxis and treatment with intravenous immunoglobulins. Clinics in Immunology and Allergy 1985;5:105-20

25. Barandum S, Imbach $P$, Kindt $\mathbf{H}$, Morell A, Nydegger UE, Römer J, Schneider T, Sidiropoulos D, Skvaril F. Clinical applications of immunoglobulin (gamma globulin). An overview 1981/82. Basel, Switzerland: Sandoz Products Ltd, 1981

26. Munster AM. Immunologic response of trauma and burns. An overview. Am J Med 1984;76(3A):142-45

27. Fehr J, Hofmann V, Kappeler U. Transient reversal of thrombocytopenia in idiopathic thrombocytopenic purpura by high-dose intravenous gamma globulin. $\mathrm{N}$ Engl J Med 1982;306:1254-9

28. Cross AS, Alving BM, Sadoff JC, Baldwin P, Terebelo H, Tang D. Intravenous immune globulin: a cautionary note [letter]. Lancet 1984;1:912

29. Evans HE, Akpata SO, Glass L. Serum immunoglobulin levels in premature and full-term infants. Am J Clin Pathol 1971;56:416-8

30. Anthony BF, Okada DM. The emergence of group B streptococci in infections of the newborn infant. Annu Rev Med 1977;28:355-69

31. Baker CJ, Kasper DL. Correlation of maternal antibody deficiency with susceptibility to neonatal group B streptococcal infection. N Engl J Med 1976;294:753-6

32. Amer J, Ott E, Ibbott FA, O'Brien D, Kempe CH. The effect of monthly gamma-globulin administration on morbidity and mortality from infection in premature infants during the first year of life. Pediatrics 1963;32:4-9

33. Steen JA. Gamma globulin in preventing infections in premature infants. Archives of Pediatrics 1960;77:291-4

34. Diamond EF, Purugganan HB, Choi HJ. Effect of prophylactic gamma globulin administration on infection morbidity in premature infants. Illinois Medical Journal 1966;130: $668-70$

35. Fischer GW, Weisman LB, Hemming VG, London WT, Hunter KW Jr, Bosworth JM Jr, Sever JL, Wilson SR, Curfman BL. Intravenous immunoglobulin in neonatal group B streptococcal disease. Pharmacokinetic and safety studies in monkeys and humans. Am J Med 1984;76(3A): 117-23

36. de Muralt G, Sidiropoulos D. Le traitement substitutif par les immunoglobulines en néonatologie. La Presse Médicale $1983 ; 12: 2595-602$

37. Christensen KK, Christensen P, Bucher HU, Duc G, Kind CH, Mieth D, Müller B, Seger RA. Intravenous administration of human IgG to newborn infants: changes in serum antibody levels to group B streptococci. Eur J Pediatr $1984 ; 143: 123-7$

38. Shigeoka AO, Hall RT, Hill HR. Blood-transfusions in groupB streptococcal sepsis. Lancet 1978;1:636-8

39. Courtney SE, Hall RT, Harris DJ. Effect of blood-transfusions on mortality in early-onset group-B streptococcal septicaemia [letter]. Lancet 1979;2:462-3
40. Sidiropoulos D, Böhme U, von Muralt G, Morell A, Barandun S. Immunoglobulinsubstitution bei der Behandlung der neonatalen Sepsis. Schweiz med Wochenschr 1981;111: 1649-55

41. Young LS. Immunoprophylaxis and serotherapy of bacterial infections. Am J Med 1984;76:664-71

42. Munster AM, Hoagland HC, Pruitt BA Jr. The effect of thermal injury on serum immunoglobulins. Ann Surg 1970; 172:965-9

43. Daniels JC, Larson DL, Abston S, Ritzmann SE. Serum protein profiles in thermal burns. I. Serum electrophoretic patterns, immunoglobulins, and transport proteins. J Trauma 1974;14:137-52

44. Kefalides NA, Arana JA, Bazan A,Bocanegra M, Stastny P, Velarde N, Rosenthal SM. Role of infection in mortality from severe burns. Evaluation of plasma, gamma-globulin, albumin and saline-solution therapy in a group of Peruvian children. N Engl J Med 1962;267:317-23

45. Stone HH, Graber CD, Martin JD Jr, Kolb L. Evaluation of gamma globulin for prophylaxis against burn sepsis. Surgery 1965;58:810-4

46. Alexander JW, Fisher MW. Immunization against Pseudomonas in infection after thermal injury. $\mathbf{J}$ Infect Dis 1974;130:S152-8

47. Jones RJ, Roe EA, Gupta JL. Controlled trial of pseudomonas immunoglobulin and vaccine in burn patients. Lancet 1980;2:1263-5

48. Pollack M. Antibody activity against Pseudomonas aeruginosa in immune globulins prepared for intravenous use in humans. J Infect Dis 1983;147:1090-8

49. Collins MS, Dorsey JH. Comparative anti-Pseudomonas aeruginosa activity of chemically modified and native immunoglobulin $\mathrm{G}$ (human), and potentiation of antibiotic protection against Pseudomonas aeruginosa and group B Streptococcus in vivo. Am J Med 1984;76(3A):155-60

50. Holder IA, Naglich JG. Experimental studies of the pathogenesis of infections due to Pseudomonas aeruginosa. Treatment with intravenous immune globulin. Am J Med 1984;76(3A):161-7

51. Collins MS, Roby RE. Protective activity of an intravenous immune globulin (human) enriched in antibody against lipopolysaccharide antigens of Pseudomonas aeruginosa. Am J Med 1984;76(3A):168-74

52. Shirani KZ, Vaughan GM, McManus AT, Amy BW, McManus WF, Pruitt BA Jr, Mason AD Jr. Replacement therapy with modified immunoglobulin $G$ in burn patients: preliminary kinetic studies. Am J Med 1984;76(3A):175-80

53. Duswald KH, Müller K, Seifert J, Ring J. Wirksamkeit von i.v. Gammaglobulin gegen bakterielle Infektionen chirurgischer Patienten Ergbnisse einer kontrolierten, randomisierten klinischen Studie. MMW 1980;122:832-6

54. Glinz W, Grob PJ, Nydegger UE, Riclin T, Stamm F, Stoffel D, Lasance A. Polyvalent immunoglobulins for prophylaxis of bacterial infections in patients following multiple trauma. Intensive Care Med 1985;11:288-94

55. Just HM, Vogel W, Metzger M, Pelka RD, Daschner FD. Treatment of intensive care unit patients with severe nosocomial infections. In: Morell A, Nydegger UE, eds. Clinical use of intravenous immunoglobulins. London: Academic Press, 1986:345-52 
56. Pfeiffer R, Kolle W. Ueber die specifische Immunitätsreaktion der Typhus-bacillen. Zeitschrift für Hygiene und Infektionskrankheiten 1896;21:203-46

57. Tate WJ III, Douglas H, Braude AI. Protection against lethality of $E$. coli endotoxin with "O" antiserum. Ann NY Acad Sci 1966;133:746-62

58. Ziegler EJ, Douglas H, Braude AI. Human antiserum for prevention of the local Shwartzman reaction and death from bacterial lipopolysaccharides. J Clin Invest 1973;52: 3236-8

59. McCabe WR. Immunization with R mutants of S. minnesota. I. Protection against challenge with heterologous gramnegative bacilli. J Immunol 1972;108:601-10

60. Ziegler EJ, Douglas H, Sherman JE, Davis CE, Braude AI. Treatment of E. coli and Klebsiella bacteremia in agranulocytic animals with antiserum to a UDP-Gal epimerasedeficient mutant. J Immunol 1973;111:433-8

61. Young LS, Stevens $P$, Ingram J. Functional role of antibody against "core" glycolipid of Enterobacteriaceae. J Clin Invest $1975 ; 56: 850-61$

62. Ziegler EJ, McCutchan JA, Douglas H, Braude AI. Prevention of lethal pseudomonas bacteremia with epimerasedeficient $E$. coli antiserum. Trans Assoc Am Physicians 1975;88:101-8

63. Marks MI, Ziegler EJ, Douglas H, Corbeil LB, Braude AI. Induction of immunity against lethal Haemophilus influenzae type b infection by Escherichia coli core lipopolysaccharide. J Clin Invest 1982;69:742-9

64. Braude AI, Douglas H. Passive immunization against the local Shwartzman reaction. J Immunol 1972;108:505-12

65. Braude AI, Douglas H, Davis CE. Treatment and prevention of intravascular coagulation with antiserum to endotoxin. J Infect Dis 1973;128 (Suppl):S157-64

66. Davis CE, Ziegler EJ, Arnold KF. Neutralization of menin gococcal endotoxin by antibody to core glycolipid. J Exp Med 1978;147:1007-17

67. Ziegler EJ, McCutchan JA, Fierer J, Glauser MP, Sadoff JC, Douglas H, Braude AI. Treatment of gram-negative bacteremia and shock with human antiserum to a mutant Escherichia coli. N Engl J Med 1982;307:1225-30

68. Baumgartner J-D, Glauser MP, McCutchan JA, Ziegler EJ, van Melle G, Klauber MR,Vogt M, Muehlen E, Luethy R, Chiolero R, Geroulanos S. Prevention of gram-negative shock and death in surgical patients by antibody to endotoxin core glycolipid. Lancet 1985;2:59-63

69. Young LS, Stevens P, Ingram J. Functional role of antibody against "core" glycolipid of Enterobacteriaceae. J Clin Invest $1975 ; 56: 850-61$

70. Warren HS, Novitsky TJ, Ketchum PA, Roslansky PF, Kania S, Siber GR. Neutralization of bacterial lipopolysaccharides by human plasma. J Clin Microbiol 1985;22:590-5

71. Tobias PS, McAdam KPWJ, Soldau K, Ulevitch RJ. Control of lipopolysaccharide-high-density lipoprotein interactions by an acute-phase reactant in human serum. Infect Immun 1985;50:73-6

72. Brade L, Brade $\mathbf{H}$. A 28,000 -dalton protein of normal mouse serum binds specifically to the inner core region of bacterial lipopolysaccharide. Infect Immun 1985;50:687-94

73. Michael JG, Whitby JL, Landry M. Increase in specific bactericidal antibodies after administration of endotoxin. Nature 1961;191:296-7

74. Rowley D, Turner KJ. Increase in macroglobulin antibodies of mouse and pig following injection of bacterial lipopolysaccharide. Immunology 1964;7:394-402

75. Baumgartner JD, O'Brien TX, Kirkland TN, Glauser MP, Ziegler EJ. Cross-reactions between antibody to the lipopolysaccharide of $E$. coli $\mathrm{J} 5$ and smooth gram-negative bacteria [abstract]. Clinical Research 1985;33:394A 